\title{
STRATEGIZING IN PLURALISTIC CONTEXTS: A NARRATIVE LITERATURE REVIEW
}

\author{
(iD) Rosalia Aldraci Barbosa Lavarda ${ }^{1}$, (D) Bárbara Zandomenico Perito ${ }^{2}$, ${ }^{\text {Elaine Rossi }}{ }^{3}$ \\ ${ }^{1}$ Doutora em Administração pela Universitat de València (Espanha).rblavarda@gmail.com \\ ${ }^{2}$ Mestranda em Administração pela Universidade Federal de Santa Catarina. bibazp@hotmail.com \\ ${ }^{3}$ Mestranda em Administração pela Universidade Federal de Santa Catarina. elaainerossi@gmail.com
}

\begin{abstract}
Objective: Considering that pluralism has been relatively ignored by classical studies on strategy, and that it is increasingly present in 21 st century organizations (Jarzabkowski \& Fenton, 2006), the goal of this study was to understand how knowledge of strategizing in pluralistic contexts has been broadened on the basis of the research conducted by Jarzabkowski and Fenton (2006)

Methods: We adopted a qualitative approach to make a narrative literature review, searching on the Ebsco, Scopus and Periódicos Capes databases. Six publications on strategizing in pluralistic contexts were selected and grouped according to their common characteristics: tensions in strategic management in pluralistic contexts; empirical studies on strategies in pluralistic contexts; and proposals on how to deal with the pluralism of organizations.

Originality/relevance: This research emphasized the importance and the need to advance the knowledge of strategies in pluralistic contexts, considering the plurality that is commonly found in contemporary organizations.

Results: Our results indicate that strategizing in pluralistic contexts is a recent topic which has been little addressed by the strategy research agenda. The six selected studies point out to tensions inherent in pluralist contexts: some address how certain environments deal with these pressures while others propose solutions to minimize the pluralism of organizations.

Theoretical/methodological contributions: Our study contributed to the compilation and analysis of the advancement of knowledge about strategizing in pluralistic contexts. We identified the rise of this field of research and stressed the need to develop this theme in view of the progress of the plurality that is present in organizations.
\end{abstract}

Keywords: Strategizing. Pluralistic contexts. Complex environments. Narrative literature review.

\section{STRATEGIZING EM CONTEXTO PLURALISTAS: UMA REVISÃO NARRATIVA DA LITERATURA}

\section{Resumo}

Objetivo: Considerando que o pluralismo vem sendo relativamente ignorado pelos estudos clássicos em estratégia, e que está cada vez mais presente nas organizações do século XXI (Jarzabkowski \& Fenton, 2006), o objetivo desta pesquisa foi compreender como ocorreu o avanço do conhecimento sobre strategizing em contextos pluralistas a partir da pesquisa de Jarzabkowski e Fenton (2006).

Método: Adotamos uma abordagem qualitativa por meio de uma revisão narrativa da literatura, com buscas nas plataformas Ebsco, Scopus and Periódicos Capes. Seis publicações sobre strategizing em contextos pluralistas foram selecionadas e agrupadas segundo suas características em comum: tensões na gestão estratégica em contextos pluralistas; estudos empíricos sobre strategizing em contextos pluralistas; e propostas sobre como lidar com o pluralismo das organizações.

Originalidade/Relevância: A relevância desta pesquisa centra-se na importância e necessidade de aprofundar o conhecimento sobre strategizing em contextos pluralistas, considerando a pluralidade que compõe as organizações contemporâneas.
Resultados: Nossos resultados indicam que o strategizing em contextos pluralistas é um tema recente e ainda pouco abordado pela agenda de pesquisa em estratégia. Os seis estudos selecionados apontam para tensões inerentes a contextos pluralistas: alguns abordam como certos ambientes lidam com essas pressões e outros propõem soluções para minimizar o pluralismo das organizações.

Contribuições teóricas/metodológicas: Nosso estudo contribuiu para a compilação e a análise acerca do avanço do conhecimento sobre strategizing em contextos pluralistas. Identificamos a ascensão do campo de pesquisa e salientamos a necessidade de desenvolver esse tema em vista do avanço da pluralidade que compõe as organizações.

Palavras-chave: Strategizing. Contextos pluralistas. Ambientes complexos. Revisão narrativa da literatura.

\section{STRATEGIZING EN CONTEXTOS PLURALISTAS: UNA REVISIÓN NARRATIVA DE LA LITERATURA}

\begin{abstract}
Resumen
Objetivo: Teniendo en cuenta que el pluralismo ha sido relativamente ignorado por los estudios clásicos en estrategia y que está cada vez más presente en las organizaciones del siglo XXI (Jarzabkowski y Fenton, 2006), el objetivo de esta investigación fue comprender cómo se dio el avance de conocimiento sobre strategizing en contextos pluralistas a partir de la investigación de Jarzabkowski y Fenton (2006).

Método: Adoptamos un enfoque cualitativo con base en una revisión narrativa de la literatura, con búsquedas en las plataformas Ebsco, Scopus y Periódicos Capes. Seis publicaciones sobre el tema fueran seleccionadas y agrupadas de acuerdo con sus características comunes: tensiones en la gestión estratégica en contextos pluralistas; estudios empíricos sobre strategizing en contextos pluralistas; y propuestas sobre cómo abordar el pluralismo de las organizaciones.

Originalidad/Relevancia: La relevancia de esta investigación reside en la importancia y la necesidad de profundizar el conocimiento sobre strategizing en contextos pluralistas, considerando la pluralidad de las organizaciones contemporáneas.

Resultados: Nuestros resultados indican que el strategizing en contextos pluralistas es un tema reciente y todavía poco abordado por la agenda de investigación en estrategia. Los seis estudios apuntan a tensiones inherentes en contextos pluralistas: nos señalan cómo ciertos entornos manejan esas presiones, y otros proponen soluciones para minimizar el pluralismo de las organizaciones.

Contribuciones teóricas/metodológicas: Nuestro estudio contribuyó a la compilación y análisis del avance del conocimiento sobre strategizing en contextos pluralistas. Identificamos el surgimiento del campo de investigación y enfatizamos la necesidad de desarrollar ese tema en vista del avance de la pluralidad en las organizaciones.
\end{abstract}

Palabras clave: Strategizing. Contextos pluralistas. Ambientes complejos. Revisión narrativa de la literatura.

\section{Como citar / Cite as}

American Psychological Association (APA)

Lavarda, R. A. B., Perito, B. Z., \& Rossi, E. (2020). Strategizing in pluralistic contexts: a narrative literature review. Iberoamerican Journal of Strategic Management (IJSM), 19(2), 125-142. https://doi.org/10.5585/riae.v19i2.16985. 


\section{Introduction}

Pluralistic organizations are characterized by having groups with diverging goals and interests, and sufficient power to ensure that their goals are legitimate for the organizational strategy (Jarzabkowski \& Fenton, 2006). In addition to distinct objectives and diffuse power, another relevant characteristic of pluralism is knowledge-based work processes (Cuccurullo \& Lega; 2013; Denis et al., 2007). All organizations have a degree of e pluralism (Denis et al., 2001). Hospitals, universities and cooperatives, for instance, have quite intense pluralistic characteristics (Brandt et al., 2017; Faraco et al., 2019).

Pluralism arises from the internal and external pressures exerted by the various stakeholders that affect the organization's strategy in some way. In this context, the creation of strategies is a complex and risky activity, since the conflicting interests of the stakeholders diminish or even prevent the multiple actors responsible for the strategy from reaching a shared consensus (Cuccurullo \& Lega; 2013). Strategy, from the perspective of strategizing, is seen as something that people do (Jarzabkowski, 2004), bringing a wide range of actors to the center of the organizational stage (Lavarda et al., 2010).

Strategizing includes all the actions, interactions and negotiations of the multiple actors in the organization, and the practices they use to carry out such activities (Jarzabkowski et al., 2007). In other words, it is the doing of strategy. This concept is explained by Jarzabkowski et al. (2007) as the intersection and confluence between practices, praxis and practitioners of the strategy. Practices refer to shared behavior routines, including traditions, rules and procedures; praxis refers to actual activity, what people do in practice; and practitioners are multiple actors in the strategy, i.e., the strategists who carry out such activity (Whittington, 2006). These elements are complementary and inseparable.

However, it is a challenge to bring all these elements together in organizational contexts of pluralism. According to Jarzabkowski and Fenton (2006), strategizing in pluralistic contexts has been largely ignored in studies of strategy, which tend to adopt coherent and unified perspectives between the study organization and its activities. The theory of strategy, according to the authors, is based on the establishment of a focus, which is inappropriate to explain strategy in pluralistic contexts, since pluralism challenges conventional conceptions of strategic decision-making (Denis et al., 2007). Thus, the great challenge facing the design and implementation of strategies in pluralistic structures is to integrate conflicting objectives (Pascucci \& Meyer, 2013).

As the theory of strategy does not take into account organizations deemed as pluralistic, and strategies can be difficult to devise and implement in these contexts, the following question arises: how has knowledge of strategizing in pluralistic contexts advanced ever since the study of Jarzabkowski and Fenton (2006) has been published? Based on this question, we aim to understand how the progress of knowledge about strategizing in pluralistic contexts occurred from Jarzabkowski and Fenton (2006). 
Understanding that the progress of knowledge about strategizing in this context is important since all organizations are pluralistic to some degree (Denis et al., 2007), and this is an increasingly relevant situation for organizations in the 21 st century (Jarzabkowski \& Fenton, 2006). As strategy studies have several limitations to pluralism, organizational research, or more precisely, strategy studies, need a shift from the current dominant perspectives towards more socially dynamic and pluralistic views (Jarzabkowski \& Fenton, 2006). Therefore, through a narrative review of the literature, we expected to contribute to updating and increasing the amount of studies on the theme, as well as to offer findings that contribute to a deeper understanding of strategizing in pluralistic contexts.

Therefore, the present work is organized as follows: Section 2 presents the methodological procedures used in the study; Section 3 reports the results, i.e., the narrative analysis of the texts grouped into three distinct categories; finally, Section 4 reports the results of the analyses per se.

\section{Methods}

This is a qualitative research study aimed at offering insights into how a certain phenomenon has occurred, namely how the knowledge of strategizing in pluralistic contexts has been advanced. Also, it can be considered as a descriptive study, as it seeks to describe the current state of the literature on the study phenomenon (Alves-Mazzotti \& Gewandsznajder, 1999; Creswell, 2010; Godoy, 1995). According to Vergara (2007), this type of study describes a certain phenomenon and establishes correlations between its variables. In this sense, by making a narrative literature analysis, this study sought to describe the above-mentioned phenomenon and correlate the bibliographical references about the target theme.

We opted for a narrative literature review, since this research strategy has been used to promote the advancement of knowledge in the field of strategy (Jarzabkowski \& Spee, 2009; Langley, 1999, 2007; Rajagopalan \& Spreitzer, 1997; Vaz \& Bulgacov, 2018). The narrative literature review is adequate to discuss the development of a certain theme, in addition to describing the state of the art from both a theoretical and an empirical point of view (Rother, 2007). Thus, the need for a narrative review of the literature depends on the abundance or scarcity of information about a given topic, as well as on divergent opinions or lack of consensus (Bolderston, 2008; Green et al., 2006).

According to Rother (2007), narrative literature reviews allow some subjectivity in the choice of authors or studies for analysis, without openly informing the source of the information being used. This is because the criteria for selecting the papers to be reviewed may not be explicitly clear and specified. In general, a narrative review of the literature can take targeted paths because of the typical rules that are inherent in this methodology (Mendes-da-Silva, 2019).

However, in order to maximize the rigor of this study, we searched for the keywords: strategizing and pluralistic contexts both in Portuguese and in English, in the Ebsco, Scopus and Periódicos Capes databases, without any other type of limiter. At first, we found 133 results and, after 
carefully reading the titles and abstracts of all papers, we listed six of them as the object of analysis in this study, as shown in Table 1. The other papers were excluded because they did not address the two terms analyzed in this research (strategizing and pluralistic contexts); they dealt with other issues in pluralistic contexts, or focused on strategizing without taking such contexts into account.

Table 1 - Selected papers

\begin{tabular}{|l|l|l|l|}
\hline \multicolumn{1}{|c|}{ Title } & \multicolumn{1}{|c|}{ Authors } & Year & \multicolumn{1}{c|}{ Journal } \\
\hline $\begin{array}{l}\text { Strategizing and Organizing in } \\
\text { Pluralistic Contexts }\end{array}$ & Jarzabkowski, P., Fenton, E. & 2006 & Long Range Planning \\
\hline $\begin{array}{l}\text { Strategizing in pluralistic contexts: } \\
\text { Rethinking theoretical frames }\end{array}$ & $\begin{array}{l}\text { Denis, Jean-Louis; Langley, } \\
\text { Ann; Rouleau, Linda }\end{array}$ & 2007 & Human Relations \\
\hline $\begin{array}{l}\text { Effective strategizing practices in } \\
\text { pluralistic settings: the case of } \\
\text { Academic Medical Centers }\end{array}$ & $\begin{array}{l}\text { Cuccurullo, Corrado; Lega, } \\
\text { Federico }\end{array}$ & 2013 & $\begin{array}{l}\text { Journal of } \\
\text { Management \& } \\
\text { Governance }\end{array}$ \\
\hline $\begin{array}{l}\text { Strategy in complex and pluralistic } \\
\text { contexts }\end{array}$ & $\begin{array}{l}\text { Pascucci, Lucilaine; Meyer, } \\
\text { Victor, Jr. }\end{array}$ & $\begin{array}{l}\text { RAC - Revista de } \\
\text { Administração } \\
\text { Contemporânea }\end{array}$ \\
\hline $\begin{array}{l}\text { Strategic management in hospitals: } \\
\text { Tensions between the managerial } \\
\text { and institutional lens }\end{array}$ & $\begin{array}{l}\text { Pascucci, Lucilaine Maria; } \\
\text { Meyer Junior, Victor; } \\
\text { Crubellate, João Marcelo }\end{array}$ & $\begin{array}{l}\text { BAR - Brazilian } \\
\text { Administration } \\
\text { Review }\end{array}$ \\
\hline $\begin{array}{l}\text { Strategies in Universities: Tensions } \\
\text { Between Macro Intentions and } \\
\text { Micro Actions }\end{array}$ & $\begin{array}{l}\text { Meyer, Victor, Jr.; Pascucci, } \\
\text { Lucilaine Maria; Meyer, } \\
\text { Bernardo }\end{array}$ & 2018 & $\begin{array}{l}\text { RAC - Revista de } \\
\text { Administração } \\
\text { Contemporânea }\end{array}$ \\
\hline
\end{tabular}

Source: Authors (2020).

The set of selected articles formed the main database for analysis of the advancement of knowledge of strategizing in pluralistic contexts. For this reason, the six studies were grouped according to their common characteristics, Table 2 shows the analytical categories that were used to streamline the analysis of the results. To achieve the objective we set for this research, we organized the articles according to their contribution to the field.

Table 2 - Categorization of the papers

\begin{tabular}{|l|l|}
\hline \multicolumn{1}{|c|}{ References } & Most relevant common features \\
\hline $\begin{array}{l}\text { Jarzabkowski, P., Fenton, E. (2006); Denis, Jean-Louis; } \\
\text { Langley, Ann; Rouleau, Linda (2007); Cuccurullo, } \\
\text { Corrado; Lega, Federico (2013). }\end{array}$ & $\begin{array}{l}\text { Propose ways to deal with the } \\
\text { pluralism of organizations }\end{array}$ \\
\hline $\begin{array}{l}\text { Cuccurullo, Corrado; Lega, Federico (2013); Pascucci, } \\
\text { Lucilaine; Meyer, Victor, Jr. (2013); Pascucci, Lucilaine } \\
\begin{array}{l}\text { Maria; Meyer Junior, Victor; Crubellate, João Marcelo } \\
\text { (2017); Meyer, Victor, Jr.; Pascucci, Lucilaine Maria; } \\
\text { Meyer, Bernardo (2018). }\end{array}\end{array}$ & $\begin{array}{l}\text { Demonstrate how strategizing occurs in } \\
\text { pluralistic contexts, reporting the } \\
\text { difficulties encountered }\end{array}$ \\
\hline
\end{tabular}


Source: Authors (2020).

Based on the application of the method, narrative analyses were made of the selected articles in order to offer an overview of the progress of studies in this area.

\section{Results}

A narrative analysis of each paper resulted in the identification of a new typology of studies about strategy in pluralistic contexts (Meyer et al., 2018; Pascucci \& Meyer, 2013; Pascucci et al. 2017). Departing from the common characteristics shared among these studies (Table 2), this section reports the contribution of such studies, according to the following categories (Table 3): (i) tensions in strategic management in pluralistic contexts; (ii) empirical studies on strategies in pluralistic contexts; and (iii) proposals on how to deal with the pluralism of organizations.

Table 3 - Key categories of the studies on strategizing in pluralistic contexts

\begin{tabular}{|l|l|}
\hline \multicolumn{1}{|c|}{ Key categories of the studies } & \multicolumn{1}{c|}{ Main references } \\
\hline $\begin{array}{l}\text { (i) Tensions in strategic management in } \\
\text { pluralistic contexts }\end{array}$ & $\begin{array}{l}\text { Jarzabkowski and Fenton (2006); Denis, Langley and } \\
\text { Rouleau (2007); Pascucci and Meyer (2013); Pascucci, } \\
\text { Meyer and Crubellate (2017); Meyer, Pascucci and Meyer } \\
\text { (2018); }\end{array}$ \\
\hline $\begin{array}{l}\text { (ii) Empirical studies on strategies in pluralistic } \\
\text { contexts }\end{array}$ & $\begin{array}{l}\text { Pascucci and Meyer (2013); Pascucci, Meyer and } \\
\text { Crubellate (2017); Meyer, Pascucci, and Meyer (2018); }\end{array}$ \\
\hline $\begin{array}{l}\text { (iii) Proposals on how to deal with the } \\
\text { pluralism of organizations }\end{array}$ & $\begin{array}{l}\text { Jarzabkowski and Fenton (2006); Denis, Langley and } \\
\text { Rouleau (2007); Cuccurullo and Lega (2013); }\end{array}$ \\
\hline
\end{tabular}

Source: Authors (2020).

As shown in Table 3, the categorization does not limit the content of the papers, nor does it exclude the possibility of similarities between separate works in the different categories. For example, a particular research study may address some points about tensions in strategic management in pluralistic contexts, even though it is primarily aimed at proposing ways of dealing with the pluralism of organizations (Allard-Poesi, 2015).

\subsection{Strategic Management Tensions in Pluralistic Contexts}

The term "strategy formation" was introduced by Mintzberg (1978), and it encompasses deliberate and emerging organizational strategies. Both the formulation and the implementation of strategies are part of a single continuous and integrated process, which relies on the involvement of strategists from different organizational levels. Thus, in the particular context of pluralistic organizations, practitioners of the strategy may be found at the various levels of the organization (Jarzabkowski, 2005). 
Pluralistic contexts are characterized by having divergent objectives, diffuse power and knowledge-based activities (Denis et al., 2007); therefore, strategy faces the problem of dealing with a multiplicity of conflicts simultaneously (Jarzabkowski \& Fenton, 2006). Pascucci and Meyer (2013) corroborate this claim when they assert that the challenge facing the development of strategies in complex environments is to integrate divergent objectives by minimizing conflicts and reconciling different interests.

Denis et al. (2007) addressed three challenges faced by strategists in organizations considered to be pluralistic. The first challenge is that plural organizations usually offer a wide scope for individual action and, consequently, people have autonomy to collaborate with organizational actions, and also to create barriers to it. The second challenge is that organizations with this characteristic seek to involve all parties when devising a strategy, which can lead to conflicts or even strategic divergences because of the individual interests of each practitioner. In this way, many ideas emerge, but there is little real action to fulfil the organization's objectives. Finally, changes can be absorbed by a sector on an individual basis, i.e., each sector or team responds to changes and promotes improvements according to its own interests.

Subsequently, some empirical studies in this category identified tensions caused by pluralism in hospitals and universities (Faraco et al., 2019; Meyer et al., 2018; Pascucci et al., 2017; Pascucci \& Meyer, 2013). In the studies by Pascucci and Meyer (2013) and Pascucci et al. (2017) in hospitals, there was similarity in the tensions generated by this context, in which plurality of interests, especially of the founders, executives and specialists, makes strategic management fundamentally political.

In the study of Meyer et al. (2018), conducted in three universities, there was a strong tension between strategic macro and micro activities, since strategic decisions are, in general, made by top managers in the organization's hierarchy, who do not prioritize or even ignore the interests of those at the bottom of the hierarchical pyramid. As a consequence, there are some conflicts and political negotiations are required to find ways to respond to the needs and interests of the entire organization (Meyer et al., 2018).

The theory about strategizing in complex contexts also shows that pluralistic organizational pressures tend to have implications; for example, emergence of strategies that go against the general objectives of the organization (Jarzabkowski \& Fenton, 2006), causing the pluralism of strategies, in which several initiatives and divergent strategic actions, with a diversity of rationalities and logics, are proposed simultaneously. Denis et al. (2007) emphasize that rational models of strategic management are of limited assistance in understanding or facing these challenges, as they have a more mechanistic perspective that does not match the characteristics of pluralism. 


\subsection{Empirical Studies on Strategizing in Pluralistic Contexts}

The research of Pascucci and Meyer (2013) made a comparative case study between the Erasto Gaertner (HEG) and Pequeno Príncipe (HPP) hospitals to analyze strategy formation and implementation in complex and pluralistic organizations. The authors found that management at HPP is traditional and familiar, and has a highly qualified management team that adopts previously consolidated tools, such as strategic planning.

In addition, Pascucci and Meyer (2013) found that the decision-making process at HPP is directly influenced by its founders. For this reason, the strategies identified in this context are essentially deliberate, and restricted to guidelines set out by senior management. Thus, the strategy formation process in this organization involved senior management and middle managers, the latter of whom had assisted autonomy, that is, they had a certain level of independence to decide or change the organization's strategic processes.

In contrast, the strategic management adopted by HEG is of a more political nature, i.e., it was composed of formal planning, according to a more rational analysis. Also, HEG has some modern management methodologies, e.g., process review and risk management; therefore, it appears to have a more professional type of management, with ordered steps and processes (Pascucci \& Meyer, 2013).

According to Pascucci and Meyer (2013), both hospitals adopt different practices, with some being more effective than others. Some examples of successful practices to deal with the inherent pluralism of these types of organizations, according to the authors, are internal forums to discuss conflicting topics, as well as democratization of decisions and encouragement of informal interactions, which allow broader participation of the employees. On the other hand, Pascucci and Meyer (2013) noticed some practices that compromised the strategy formation process, such as inflexibility of goals, rigor of strategic planning (verified in HEG) and other practices of this nature.

In general, Pascucci and Meyer (2013) highlighted that the strategic actions in the study organizations were found to be poorly integrated and influenced by informal interactions. They also identified a pattern of behavior in strategy formation in this context (Table 4). 
Table 4 - Pattern identified in strategy formation of the study hospitals

\begin{tabular}{|c|c|}
\hline Characteristics & Strategy formation in hospitals: identified pattern \\
\hline Thinking & Informal, with rules \\
\hline Dominant cognitive style & Interpretative \\
\hline Emphasis & Creativity over logic \\
\hline Direction of thought & Lateral \\
\hline Posture towards the future & Flexible and bold \\
\hline Nature of the strategy & Emerging over deliberate \\
\hline Formation process & Essentially adaptive and creative \\
\hline Strategists & Thinking and acting intertwined \\
\hline Decision-making & At all levels of the organization \\
\hline Interactions & Scattered \\
\hline Changes & Evolutionary \\
\hline Posture in changes & Balanced between conflict and consensus \\
\hline Execution & Iterative \\
\hline Execution focus & Learning \\
\hline Autonomy & Assisted in different functions \\
\hline Support & Result of flexibility and negotiation \\
\hline
\end{tabular}

Source: Translated from Pascucci and Meyer (2013).

At the end of the research, Pascucci and Meyer (2013) also pointed out that there was a predominance of emerging strategies, mostly adjustments to meet long-term goals (Da Silva, 2019). In addition, they showed a much higher incidence of praxis than strategic practices (praxis is defined as strategic action itself and practices are defined as behavioral patterns, e.g., traditions). Also, assisted autonomy proved to be fundamental in the management of pluralistic organizations. Therefore, a minimum level of autonomy is essential for the creation of new praxes that contribute to the evolution of the strategic practices of pluralistic organizations (Pascucci \& Meyer, 2013).

A more recent study, by Pascucci et al. (2017), also conducted in hospitals, was aimed at analyzing how strategic management contributed to reducing tensions arising from managerial factors and institutional logics. The hospitals analyzed in their study were the same as in the previous study by Pascucci and Meyer (2013). In this case, Pascucci et al. (2017) found that the use of strategic planning as a management mechanism came into conflict with the unpredictability of the pluralistic context of the study hospitals, as well as with other difficulties faced by these organizations in particular, such as scarcity of resources because of their philanthropic nature. 
Such evidence corroborated the importance of flexibility and adaptability of agents in strategic management, as previously argued by McDaniel (2007). Hospitals, however, had to seek mechanisms to address such dynamics. HPP adopted the use of project management, ensuring the relationship of each strategy with its purposes. This practice was confirmed to offer many benefits. As pointed out by the interviewees, planning has become more dynamic, following the organization's logistics. Thus, as good results had been achieved over time, the practice of project management has become institutionalized.

Another issue in the research of Pascucci et al. (2017) was the fact that HPP's top management is more flexible and able to negotiate with all hierarchical levels of the organization, while in the case of HEG, management was more formal, creating a gap between the head and body of the organization, which generated tensions between sectors. Although the institutional mission of hospitals integrates divergent views and interests between hierarchical levels and motivates cultural change within the organization, it is common for managers to fail to achieve them adequately (Pascucci et al., 2017).

The study also identified that the use of strategic management models imported from business organizations, with high levels of rationality, are not mechanisms that are easily adapted to hospital contexts. Managers of contexts with a high level of pluralism, such as hospitals, deal with tensions and conflicts that require experience and cumulative tacit knowledge to be resolved (Jarzabkowski et al., 2007), since the performance of these organizations depends essentially on balance between their logics (Pascucci et al., 2017).

Concluding the analysis, Pascucci et al. (2017) emphasize that strategic management in pluralistic contexts is a highly dynamic process, in which institutional factors play an important role, as measured by their results. Therefore, improving the way strategies are managed in pluralistic contexts requires that leaders pay attention to the complex nature of these organizations. In this context, flexibility, adaptability, creativity and informal actions and interactions are aspects that enable the emergence of autonomous actions and contribute to the development of the strategy (Andersen, 2000; Jarzabkowski et al., 2007).

Universities are another type of highly complex and pluralistic organization. A study by Meyer et al. (2018), through a comparison between three Brazilian universities, analyzed how academic strategies are impacted by tensions triggered by the macro intentions of top management and by the micro actions of academic management. This study is important for the strategic management of universities, especially because in this context, it is often difficult to align the organizational objectives with the specific interests of academic units (Meyer et al., 2018).

An important point observed at the three universities analyzed in that study is the concentration of strategic decisions at the top of the hierarchy. Depending on the nature of the problem or the decision that needs to be made, the leader of an interest group is called to participate in the discussion in order to legitimize the decisions that are made, because the strategies are always decided by the top management 
and the department heads are involved only because it is up to them to convince professors that the decision made was the best one (Meyer et al., 2018).

The plurality of interests and the ambiguity of organizational objectives in universities leave room for different interpretations and actions in relation to a particular reality, causing the lack of alignment between senior management and the micro actions practiced daily in the academic area. A major finding in this research, according to Meyer et al. (2018), was that most of the strategic actions effectively carried out on a daily basis in universities are spontaneous initiatives by academic managers and professors, rather than the result of the strategic planning proposed by top management. However, there was a significant gap between the strategic intentions and the actions themselves.

The strategies developed at universities, therefore, are better represented by micro actions than by practices derived from strategic planning. It should also be noted that, in this context, rationalized practices, arising from strategic planning, act as barriers. In two of the three universities analyzed, strategic planning was inefficient and detrimental to academic logic. Another important point to be highlighted is that top management sees the university as a highly competitive environment, based on a defined hierarchy, which aims to produce knowledge (Meyer et al., 2018).

Finally, Meyer et al. (2018) emphasize that the management of academic organizations is too important to be left in the hands of professionals with the wrong ideas on how to manage higher education institutions, who overestimate strategic planning (Meyer et al., 2018). In fact, based on the studies mentioned above, it appears that strategic planning is not effective in directing academic microcells, where strategic actions take place. Johnson, Melin and Whittington (2003) argue that it is at the micro-organizational level, that is, in routine practices, that strategy takes place. In this sense, emerging actions must complement strategic planning, especially to improve the performance of organizations in more complex environments (Andersen, 2000).

\subsection{Proposals on How to Deal with Pluralism in Organizations}

Among the six articles selected as the basis for this study, three of them suggest ways to deal with pluralism in organizations. The first is the one that started studies on strategizing in pluralistic contexts, the article by Jarzabkowski and Fenton (2006). In this article, Jarzabkowski and Fenton (2006) highlight that strategizing in pluralistic contexts has been ignored by the strategy theory, which usually adopts a more coherent view of the company and its activities and does not take into account the divergent objectives and the diffuse power that can exist within organizations (Jarzabkowski \& Fenton, 2006).

Taking into account the pressures that pluralism exerts on strategists, Jarzabkowski and Fenton (2006) proposed three modes of association between strategizing and structuring pluralistic organizations. In Figure 1, these three modes can be seen in a decreasing order, from the best to the worst, or from the ideal to the least advisable. 
Figure 1 - Implications of modes of association between organizing and strategizing

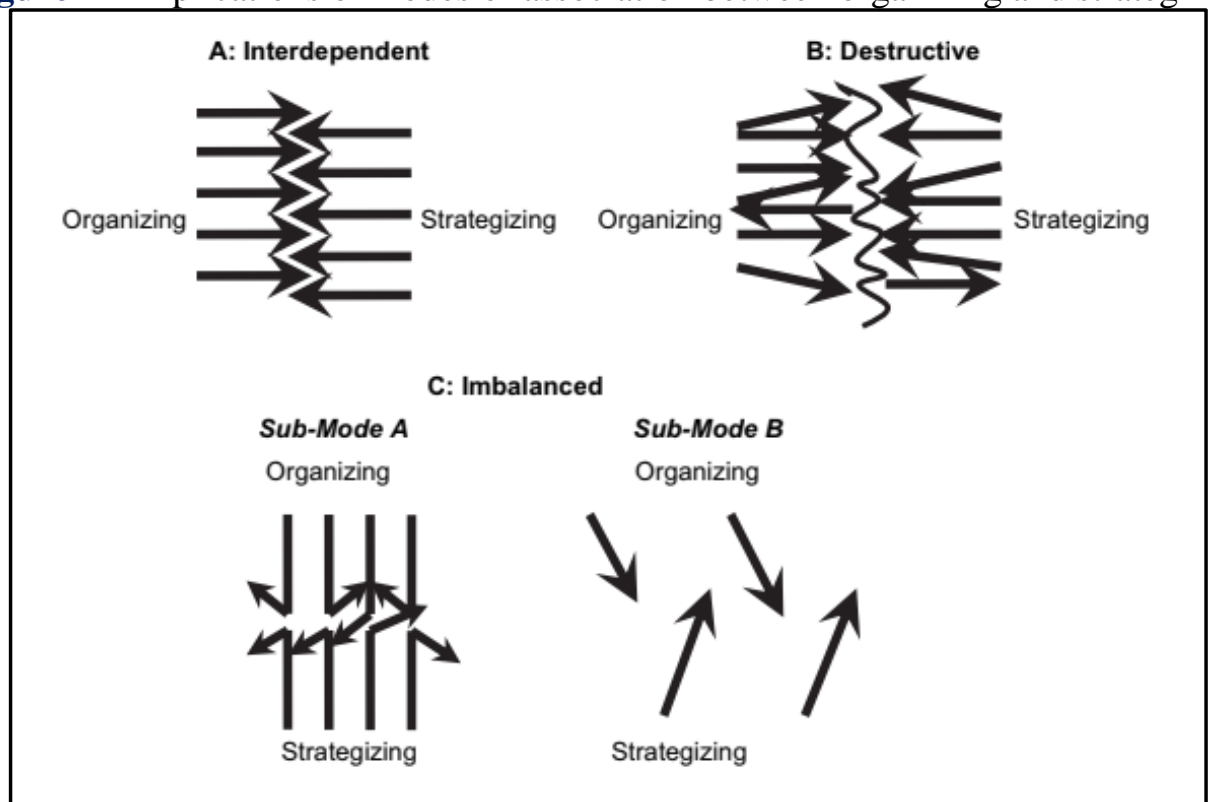

Source: Jarzabkowski and Fenton (2006, p. 642).

The interdependent mode (A), considered as the ideal situation for organizations exposed to pluralism, occurs at the moment when the organization's structuring and strategizing reinforce each other, which is when the organizational practices are adapted to the demands of different strategic objectives and strategic practices recognize the interests and identities of different organizational groups. Therefore, managers need to recognize the existence of pluralism to achieve this interdependence. Achieving the interdependence between strategy making and structuring requires time and continuous flexibility in adjusting the organization, and the organization needs to assume flexibility as part of the strategy. Therefore, interdependence is not a stable state but an ideal state that organizations need to strive for continuously (Jarzabkowski \& Fenton, 2006).

At the other extreme, a destructive association (B) is usually caused by extreme pluralism, in which divergent objectives cannot be aligned or are in conflict with strategic objectives. In this case, the organization is pulled in many directions inward, and is strained to resolve multiple demands simultaneously. However, Jarzabkowski \& Fenton (2006) propose some ways that can minimize the consequences of this excessive pluralism: the first one is to fragment the organization into smaller groups, minimizing the complexity of the groups and adapting the strategies according to each team; and to identify the different interests on the part of the managers, and promote dialogue about the multiple existing expectations.

Between the interdependent and the destructive association, there is the imbalanced one (C), which normally happens when managers do not recognize organizational pluralism. In this case, pluralism leads to imbalanced structuring and strategizing, blocking or preventing the emergence of new strategic practices. When practices are rigid, without constant adjustment, the organization is prone to imbalance, precisely because of the lack of flexibility proposed in the interdependent association. 
Finally, Jarzabkowski \& Fenton (2006) emphasize that it is essential that managers become aware of and assume the complexity of the organization they are managing, and try to reach the interdependent state (A), adapting the practices of their organizations to the demands of different strategic objectives, recognizing the interests and identities of different organizational groups. To do so, managers need to recognize that it will never be a stable state and will need continuous effort.

Then, Denis et al. (2007) designed a very complex research study that looks at strategizing in pluralistic contexts using three theoretical perspectives as a basis: the Actor-Network Theory (ANT); the Conventionalist Theory (CT); and Strategy as a Social Practice (SAP). The ANT, CT and SAP approaches consider strategy, respectively, as a translation process, an accommodation process and a social practice (Denis et al., 2007).

Regarding the first theoretical approach, Denis et al. (2007) highlights that ANT describes and explains how support networks can be built so that strategies and decisions are taken for granted, despite the fragmentation of objectives and power in the pluralistic context. ANT also draws attention to the way in which objects have the power to become actors within a network, actively contributing to the development of strategies. The authors point out that there are few empirical studies analyzing the use of this approach in complex environments, but these works suggest that future research could be conducted, using this theory, to broaden the understanding of strategizing in pluralistic contexts. It should also be noted that strategists who use this lens recognize the need to think simultaneously about organizational strategies and support networks in which they can get involved.

In the second theoretical approach, $\mathrm{CT}$ adds strategizing in pluralistic contexts when it perceives strategy as a convention or a sustainable compromise between divergent values. In this perspective, organizational strategies are the result of deliberate and emerging actions, which are legitimized when multiple logics are ordered by various stakeholders inside and outside the organization. In this sense, strategizing is seen as an accommodation process because it consists of a set of processes that generate accommodation between competing values that cannot be discarded, and that at the same time are sources of tension. Thus, according to Denis et al. (2007), strategists are seen as critical individuals, capable of navigating with credibility between different worlds of values.

However, the third approach, from SAP, considers strategy a social practice, represented by a set of social interactions, routines and conversations through which managers design the organization's strategies. Therefore, in this case, strategizing is conceived as a practice involving multiple individuals, whether they are managers or not, taking into account any and every action that happens in the organization on a daily basis. Also, Langley and Rouleau (2007) highlight that a strategist who uses this lens considers micro interactions to be very important for the organization's direction.

Each of these three perspectives focuses on different levels and different units of analysis (Denis et al., 2007). While ANT focuses on the meso organizational level, CT is concerned with the macro while SAP focuses on the micro level of the organization. Therefore, as regards strategizing in pluralistic contexts, these approaches can be considered complementary to each other, since each one approaches 
strategizing from a different angle. Thus, based on these complementarities, Denis et al. (2007) proposed an ideal model for strategizing in complex environments (Figure 2).

Figure 2 - Strategizing in pluralistic contexts at the intersection of theoretical frames

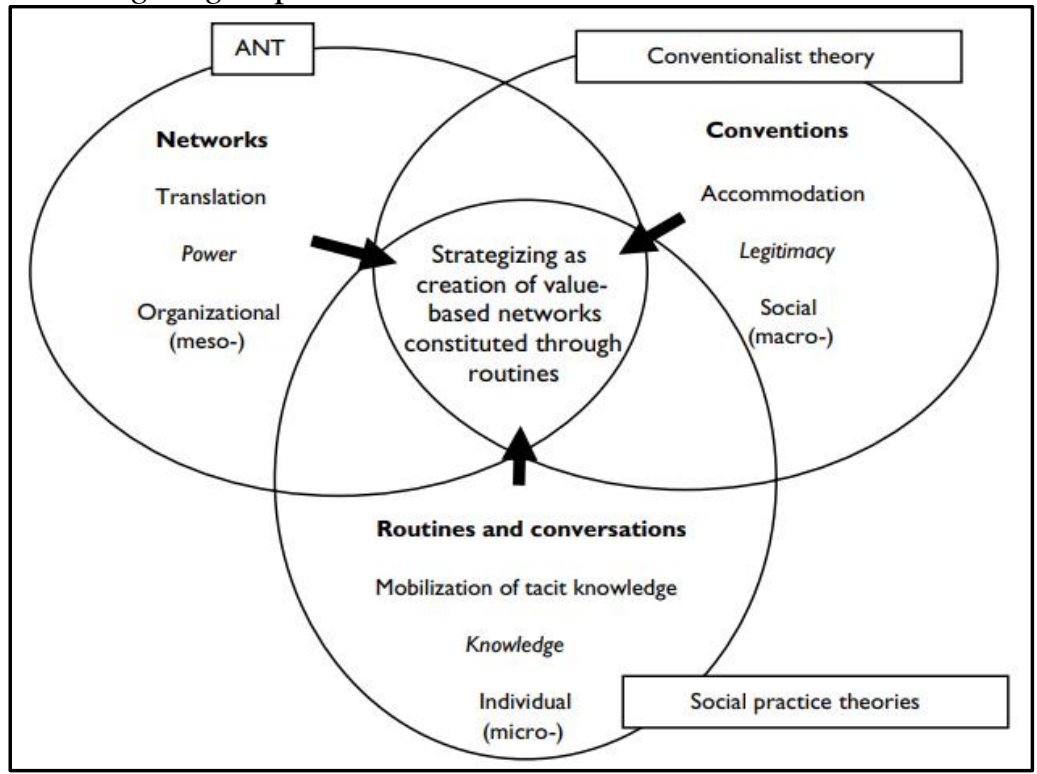

Source: Denis et al. (2007, p. 208).

The perspectives of ANT, CT and SAP offer a vision of the strategy-making process in pluralistic contexts that has real plausibility. Denis et al. (2007) underscore that the relationship networks between human and non-human actors, for example, must be based on values, and this can be achieved through the daily micro activities proposed by SAP.

In 2011, a study that analyzed how strategic processes are constructed in university hospitals and what practices could be adopted in such contexts (Cuccurullo \& Lega, 2013), also brought valid contributions to the pluralistic organizational scenario. The first one is that pluralism is minimized by increasing participation in the formulation and strategic implementation by members of the organization. Cuccurullo and Lega (2013) argue that participatory strategic practices are more effective than the strategic practices of rational models. Several authors agree with this statement and corroborate it by stating that the participation of several actors in decision making is recognized as the best practice, in addition to the fact that participation is important to support the implementation of strategies (Floyd \& Lane, 2000; Hodgkinson \& Sparrow, 2002; Jarzabkowski \& Balogun, 2009).

For the rationalization of political games promoted by divergent interests within pluralistic contexts, Cuccurullo and Lega (2013) point to the use of quantitative data as an artifact to convince stakeholders that a decision that needs to be taken, since quantitative data avoid individual opinions. Moreover, visual artifacts can improve the quality of the strategic planning process, since graphic representations create a shared system of meanings, making the discussions about strategy more participatory and more balanced (Cuccurullo \& Lega, 2013). 


\subsection{Reflection on the research question and new directions}

Considering the initial research question: how has knowledge of strategizing in pluralistic contexts been broadened on the basis of the research conducted by Jarzabkowski and Fenton (2006)?, we found that this field of study is quite recent and unexplored, as only six scientific articles addressing the theme have been published so far. For this reason, this is a fertile field that offers numerous opportunities for future research. In Figure 3, we compiled our research on the advancement of knowledge of strategizing in pluralistic contexts, based on the work of Jarzabkowski and Fenton (2006).

Figure 3 - Progress of knowledge about strategizing in pluralistic contexts

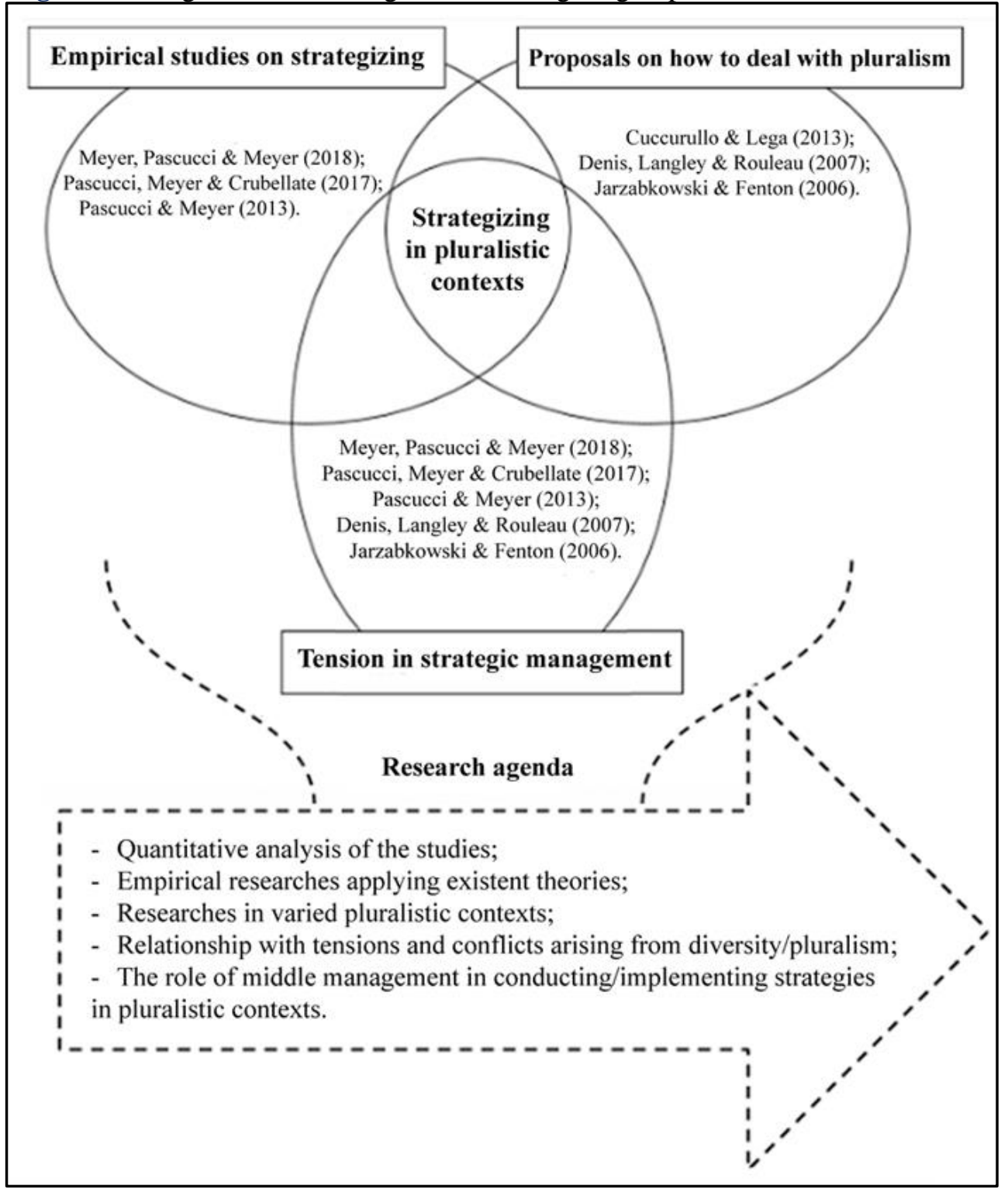

Source: Authors (2020).

From the qualitative literature review, we understood that the six studies are complementary to each other, since they all raise tensions inherent in pluralistic contexts. While some articles address how 
certain environments deal with these pressures (Cuccurullo \& Lega, 2013; Pascucci \& Meyer, 2013; Pascucci et al., 2017; Meyer et al., 2018), others propose solutions to minimize the pluralism of organizations (Jarzabkowski \& Fenton, 2006; Denis et al., 2007; Cuccurullo \& Lega, 2013).

As for tensions and conflicts, we found that, just as people have autonomy to collaborate with strategic actions, they also have autonomy to create a barrier to them (Denis et al., 2007). In addition, some of the actions appear to differ from the organization's objectives, and may even be in total opposition (Denis et al., 2007; Jarzabkowski \& Fenton, 2006). Finally, the plurality of interests between macro and strategic micro-activities makes strategic management fundamentally political (Denis et al., 2007; Meyer et al., 2018).

Still, as previously presented, strategizing includes all the actions, interactions and negotiations of the multiple actors of the organization, and the practices used by them to carry out such activities (Jarzabkowski et al., 2007). It is increasingly important to understand that those who participate in strategic action, regardless of organizational level, play a relevant role and contribute to achieving the desired results. To obtain greater involvement and engagement to the strategic practices, top management members need to open the strategic process of their organizations, increasing the visibility of strategic information and including all participants involved in these processes that are designed to shape the strategy (Lavarda et al., 2010; Venancio et al., 2016).

Therefore, strategic activity can be considered a complex activity; it is one of the problems faced by managers in their actual practices (Da Silva, 2019), formed in the interactions between multiple organizational productions of contrasting nature. Thus, strategy formation should not be centered only on interactions considered as strategic or on narratives considered to be dominant; rather, top management must take into account the multiplicity of voices, actions and narratives of the different actors in the organization when devising the strategy (De La Ville; Mounoud, 2015).

\section{Final remarks}

The goal of this study was to understand how knowledge of strategizing in pluralistic contexts has been broadened on the basis of the research conducted by Jarzabkowski and Fenton (2006). Based on a narrative review of the literature, we could achieve this objective and find that the advancement of such knowledge is still slow, although it has room to increase.

The essential contribution of this research is precisely to point out the need to develop this theme further in view of the advancement of the plurality that is found in organizations (Meyer et al., 2018; Pascucci et al., 2017).

The narrative review of the literature contributes to the compilation and analysis of studies in a certain field, as well as an in-depth description of how these subjects have been discussed in the literature. In the case of strategizing in pluralistic contexts, it is clear that there has been an evolution of publications over time, since the first studies proposed solutions to the tensions caused by pluralism, 
while more recent research brought empirical approaches based on the theory raised previously. Thus, it seems to be evident that this field of research is on the rise, as well as pluralism is present and is more and more notorious in 21st century organizations (Jarzabkowski \& Fenton, 2006).

The proposed research agenda (Figure 3) is the main contribution of this study. We suggest that researchers explore different possibilities of addressing the strategy-as-practice agenda: a quantitative analysis of this same study; empirical research applying existing theories; research on various pluralist contexts; research on the tensions and conflicts arising from diversity/pluralism, and on the role of the middle managers in driving/implementing strategies in pluralistic contexts.

As limitations presented by this narrative review of the literature, it is important to highlight that the references selected for this analysis carry a conceptual bias related to the profile of the researchers. Another limitation is the definition of the methodology itself, as it allows only qualitative, but not quantitative, analysis of selected publications.

Therefore, for future studies, a combination with bibliography or systematic literature review would be appropriate, as it would enable a quantitative analysis of the works and, consequently, a greater generalization of the results. In addition, future empirical research could be conducted by applying the theories discussed here in the most varied pluralistic contexts.

As future research, specifically, we indicate the potential to analyze the field empirically, checking how organizations actually deal with pluralism in different degrees, in addition to exploring this approach further, with theoretical research intersecting with other relevant topics, e.g., openness in strategy (Hautz et al., 2017; Whittington et al., 2011) or the relationship with the tensions and conflicts arising from diversity/plurality and the role of the intermediate level (middle manager) in conducting or implementing the strategy in pluralistic environments.

Finally, this work presented contextual, methodological and theoretical aspects inherent in research on strategizing in pluralistic contexts, opening up a range of opportunities for future research aimed at analyzing related issues mode deeply, e.g., the tensions and conflicts arising from the plurality/diversity in the design or in the implementation of the strategy or how certain organizations in specific environments deal with these tensions and conflicts.

Thus, broadening the knowledge of strategizing in pluralistic contexts is extremely important because of the advancement of the plurality that is commonly found in contemporary organizations.

\section{References}

Allard-Poesi, F. (2010). A Foucauldian perspective on strategic practice: strategy as the art of (un) folding. Cambridge handbook of strategy as practice, 1966, 168.

Alves-Mazzotti, A. J., \& Gewandsznajder, F. (1999). O planejamento de pesquisas qualitativas. . O método nas ciências naturais e sociais: pesquisa quantitativa e qualitativa, 2, 147-176.

Andersen, T. J. (2000). Strategic planning, autonomous actions and corporate performance. Long range planning, 33(2), 184-200. 
Bolderston, A. (2008). Writing an effective literature review. Journal of Medical Imaging and Radiation Sciences, 39(2), 86-92.

Brandt, J. Z., Lavarda, R. A. B., Pereira, M. A. S., \& Lozano, L. (2017). Estratégia-como-prática social para a construção da perspectiva de gênero nas políticas públicas em Florianópolis. Revista de Administração Pública-RAP, 51(1), 64-87.

Creswell, J. W. (2010). Mapping the developing landscape of mixed methods research. SAGE handbook of mixed methods in social \& behavioral research, 2, 45-68.

Cuccurullo, C., \& Lega, F. (2013). Effective strategizing practices in pluralistic settings: the case of Academic Medical Centers. Journal of Management \& Governance, 17(3), 609-629.

de La Ville, V. I., \& Mounoud, E. (2010). A narrative approach to strategy as practice: strategy making from texts and narratives. Cambridge handbook of strategy as practice, 183-197.

da Silva, S. S., Spers, R. G., Oliveira, M. A., \& Fischmann, A. A. (2019). The Strategic Management Practice in an Online Experiential Learning Laboratory. Iberoamerican Journal of Strategic Management (IJSM), 18(3).

Denis, J. L., Lamothe, L., \& Langley, A. (2001). The dynamics of collective leadership and strategic change in pluralistic organizations. Academy of Management journal, 44(4), 809-837.

Denis, J. L., Langley, A., \& Rouleau, L. (2007). Strategizing in pluralistic contexts: Rethinking theoretical frames. Human relations, 60(1), 179-215.

Faraco, M. M., Lavarda, R. A. B., \& Gelbcke, F. L. (2019). Tomada de decisão em hospitais de ensino: entre formalismo e síntese intuitiva. Revista de Administração Pública, 53(4), 769-779.

Floyd, S. W., \& Lane, P. J. (2000). Strategizing throughout the organization: Managing role conflict in strategic renewal. Academy of management review, 25(1), 154-177.

Godoy, A. S. (1995). Introdução à pesquisa qualitativa e suas possibilidades. RAE-revista de administração de empresas, 35(2), 57-63.

Green, B. N., Johnson, C. D., \& Adams, A. (2006). Writing narrative literature reviews for peerreviewed journals: secrets of the trade. Journal of chiropractic medicine, 5(3), 101-117.

Hautz, J., Seidl, D., \& Whittington, R. (2017). Open strategy: Dimensions, dilemmas, dynamics. Long Range Planning, 50(3), 298-309.

Hodgkinson, G. P., \& Sparrow, P. (2002). The competent organization: A psychological analysis of the strategic management process (Vol. 154). Buckingham: Open University Press.

Jarzabkowski, P., \& Wilson, D. C. (2004). Pensando e agindo estrategicamente: novos desafios para a análise estratégica. $R A E, 44(4), 11-20$.

Jarzabkowski, P. (2005). Strategy as practice: An activity based approach. Sage.

Jarzabkowski, P., \& Balogun, J. (2009). The practice and process of delivering integration through strategic planning. Journal of Management Studies, 46(8), 1255-1288.

Jarzabkowski, P., Balogun, J., \& Seidl, D. (2007). Strategizing: The challenges of a practice perspective. Human relations, 60(1), 5-27.

Jarzabkowski, P., \& Fenton, E. (2006). Strategizing and organizing in pluralistic contexts. Long Range Planning, 39(6), 631-648.

Jarzabkowski, P., \& Paul Spee, A. (2009). Strategy-as-practice: A review and future directions for the field. International journal of management reviews, 11(1), 69-95.

Johnson, G., Melin, L., \& Whittington, R. (2003). Micro strategy and strategizing: towards an activitybased view. Journal of management studies, 40(1), 3-22.

Langley, A. (1999). Strategies for theorizing from process data. Academy of Management review, 24(4), 691-710.

Langley, A. (2007). Process thinking in strategic organization. Strategic organization, 5(3), 271-282.

Lavarda, R. A. B., Canet-Giner, M. T., \& Peris-Bonet, F. J. (2010). How middle managers contribute to strategy formation process: connection of strategy processes and strategy practices. Revista de Administração de Empresas, 50(4), 358-370.

Mendes-Da-Silva, W. (2019). Contribuições e limitações de revisões narrativas e revisões sistemáticas na área de negócios. Revista de Administração Contemporânea, 23(2), 1-11.

Meyer Junior, V., Pascucci, L. M., \& Meyer, B. (2018). Strategies in universities: tensions between macro intentions and micro actions. Revista de Administração Contemporânea, 22(2), 163-177.

McDaniel Jr, R. R. (2007). Management strategies for complex adaptive systems sensemaking, learning, and improvisation. Performance Improvement Quarterly, 20(2), 21-41. 
Mintzberg, H. (1978). Patterns in strategy formation. Management science, 24(9), 934-948.

Pascucci, L., \& Meyer Jr, V. (2013). Estratégia em contextos complexos e pluralísticos. Revista de Administração Contemporânea, 17(5), 536-555.

Pascucci, L. M., Meyer Júnior, V., \& Crubellate, J. M. (2017). Strategic management in hospitals: Tensions between the managerial and institutional lens. BAR-Brazilian Administration Review, 14(2).

Rajagopalan, N., \& Spreitzer, G. M. (1997). Toward a theory of strategic change: A multi-lens perspective and integrative framework. Academy of management review, 22(1), 48-79.

Rother, E. T. (2007). Revisão sistemática X revisão narrativa. Acta paulista de enfermagem, 20(2), vvi.

Vaz, S. L., \& Bulgacov, S. (2018). Envolvimento Estratégico da Média Gerência: Analisando o Passado e Projetando o Futuro. Revista de Administração Contemporânea, 22(3), 380-402.

Venancio, D. M., Lavarda, R. B., \& Fiates, G. G. S. (2016). O Papel da Gerência Intermediária na Formação da Estratégia. Revista Ibero Americana de Estratégia, 15(4), $28-42$.

Vergara, S. C. (2006). Projetos e relatórios de pesquisa. São Paulo: Atlas.

Whittington, R. (2006). Completing the practice turn in strategy research. Organization studies, 27(5), 613-634.

Whittington, R., Cailluet, L., \& Yakis-Douglas, B. (2011). Opening strategy: Evolution of a precarious profession. British Journal of Management, 22(3), 531-544. 